\title{
Kvinnlig intimitet och manlig solidaritet: Binamnens könade maktstrukturer
}

\section{Linnea Gustafsson}

Det rådande genusteoretiska paradigmet kallas ofta för den tredje vågens feminism och detta paradigm har till stor del influerats av Michel Foucaults (t.ex. 1981) teoretisering av makt. Enligt Foucault ses makt som ett nät av relationer snarare än regelrätt överordning som eventuellt kombineras med en formell position. I och med Foucaults utgångspunkt impliceras också ett maktspel varje gång mellanmänsklig interaktion äger rum eftersom språket, som bärare av relationer, förmedlar maktstrukturer (Thornborrow 2002:7ff.). Skapandet och återskapandet av maktstrukturerna i den pågående språkliga diskursen är samtidigt bedrägligt eftersom det sker på ett så välbekant och konventionell sätt - genom alldaglig interaktion - att vi inte ens lägger märke till att det händer och inte ser betydelsen av det (Cameron 1990:14). Sett på det här sättet uppfattas makt som mycket mer vardagligt än som en abstrakt kraft som snarare påtvingas uppifrån.

Ett av de språkliga sätt som kan användas för att både spegla och upprätthålla existerande sociala relationer och identiteter är benämning av personer, något som är ett val som får konsekvenser (Talbot 1998:217, Cameron 1995:143). Benämnandet sker främst genom tilltal eller omtal, och därför är det relevant att studera dessa mönster som förekommer i språket.

Mot den här bakgrunden är tilltalet, t.ex. smädeord, titlar, namn, pronomen och binamn, ett språkligt val som markerar sociala relationer. Följden blir att alla tilltalsformer är socialt laddade, men exakt vad varje etikettering innebär eller gör med samtalsdeltagarna, beror på hur yttrandet passar in i andra aspekter av den sociala praktikgemenskapen. Rent grammatiskt behövs inte alltid ett tilltalsord, men i det sociala samspelet krävs ofta ett specifikt tilltal som då automatiskt för med sig den här laddningen (McConnell-Ginet 2003:77). Att bryta sociala samtalsregler som finns kan vara kostsamt för individen, eftersom det kan beskrivas som ett begränsande av handlingsutrymmet - sändarens eller mottagarens - eller en självbild som ska stå tillbaka för den andra (Brown \& Levinson 1987:67 ff.). Med ett genusperspektiv på det här resonemanget konstaterar Margaret Deuchar (1988:29 ff.) att en anledning till kvinnors mer utbredda användning av standardspråk kan vara en konsekvens av den respekt som de visar för sin samtalspartners självbild.

När samtalsdeltagare med språkets hjälp formulerar medlemskap i praktikgemenskaper konstrueras identiteter som inkluderar genusidentiteter (McConnell-Ginet 2003:71; Mills 2008:61 ff.). Genom att upprepa handlingar som anses typiska för en viss identitet är det möjligt att skapa och återskapa identiteter, t.ex. genus. Härigenom görs kön (Butler 2004:91 ff., 1990:136 ff.). Inom språkvetenskapen har det uppmärksammats att interaktionen är ett viktigt verktyg för det här återskapandet av kön (West \& Zimmerman 1987:137ff.). En typ av vardaglig interaktion är namnhandlingar - namngivning och namnanvändning - som i den här artikeln representeras av binamn. Genom att välja, eller inte välja, vissa typer av binamn och binamnshandlingar kan namngivaren skapa och återskapa identiteter. Tilltal ska i det här 
sammanhanget ses som en illokut språkhandling med en användning som kan förändra hela situationer, på samma sätt som äktenskapslöften som uttalas inför vigselförrättaren (Austin 1975:4 ff.).

Konsekvensen blir att det är relevant att studera hur kvinnor respektive män tilltalas och omtalas ur ett genusperspektiv. Beträffande omtalet av kvinnor finns en svensk undersökning av smädeord som visar hur vulgärt språkbruk om både kvinnor och män används för att upprätthålla kulturella tabun där kvinnor inte bör vara lidelsefulla och män inte omanliga (Svahn 1999:185).

En annan väl analyserad del i många språk, däribland svenska, är de pronomenformer där sändaren tvingas välja mellan han eller hon (eller motsvarande i andra språk) i tredje person singularis. När språkbrukarna väljer han som generiskt pronomen tolkas detta ofta som osynliggörande av kvinnor (Cameron 1990:12; Gastil 1990:630 ff.; Mills 2008:47 f.). I Sverige har den här debatten influerats av ett normkritiskt perspektiv där språkbrukarna själva har introducerat det könsneutrala pronomenet hen (Wojahn 2015:217 ff.; Milles 2008:48 ff.). Samma osynliggörande av kvinnor förekommer vid pronomenet man liksom vid vissa yrkestitlar där språkbrukarna ibland aktivt bytt ut eller ändrat ordet för att dess konnotationer ska uppfattas annorlunda. Förändringarna är dock inte alltid konsekvent genomförda och de ofta har föregåtts av diskussioner. På svenska har t.ex. justeringsman bytts till justerare, riksdagsman till riksdagsledamot och i engelskan har t.ex. policeman och fireman ändrats till police officer respektive firefighter (Milles 2008:35 ff.; Mills 2008:49ff.; Pauwels 2003:561 ff.). På engelskt språkområde har det dessutom funnits en diskussion beträffande titlar såsom $\mathrm{Mrs}$ eller Miss som markerar kvinnans civilstånd, till skillnad från $M r$ som är detsamma för mannen oavsett hans äktenskapliga band (Pauwels 1996, 2003:565f.).

Gemensamt för de tilltals- och omtalsundersökningar som jag känner till är att de baseras på antingen uttalat negativa uttryck eller rena osynliggöranden av kvinnor. Däremot framstår det inte lika tydligt att det kan förekomma benämnanden som låter positiva, men som trots allt kan innehålla en maktaspekt. Med andra ord, uttryck där det känslomässiga engagemanget är både kärleksfullt och fientligt på samma gång (Connell 2009:112). För att diskutera det här har jag valt att använda ett modernt vardagligt binamnsmaterial. De frågor som jag specifikt diskuterar i artikeln är:

- Hur ser kvinnors respektive mäns binamn ut?

- I vilka tillkomstmiljöer får kvinnor respektive män binamn och hur ser maktfördelningen i dessa miljöer ut?

Binamn är den språkvetenskapliga termen för att beteckna en ganska diversifierad namngrupp som består av både smeknamn och öknamn. Termen är ganska otydlig med både en historisk och en samtida förståelse som kan svara mot olika behov. Vid studiet av ett modernt binamnsmaterial är det viktigt att dra en gräns mellan binamn och förnamn. En viktig skillnad är att binamn inte existerar i några register och därmed kan de vara mindre beständiga. Binamn tenderar också att intimisera relationen mellan sändare och mottagare på antingen ett positivt eller ett negativt sätt och de kan vara starkt situations- och gruppbundna. Följaktligen kan binamnen i större utsträckning än förnamnen röra sig mellan olika funktionsområden 
(Gustafsson 2016:30f.). Den definition av binamn som används utgår från namnbrukarnas tolkning av namntypen och följaktligen kan namnkaraktären variera mellan olika binamn i materialet. Ibland har binamnet hämtats från ett konventionellt binamnsonomastikon, t.ex. Olle, Sussi och Tobbe, och andra gånger har det hämtats från vårt lexikon, oftast i form av ett substantiv, t.ex. Myran, Sköldpaddan och Sorken. Därmed betraktas ett binamn som ett ersättningsnamn för namnbärarens förnamn i materialet (Gustafsson 2016, se avsnitt 1.6).

\section{Personnamn och genus}

Med avseende på genus har personnamn och personnamnsgivning diskuterats från flera infallsvinklar. En anledning till intresset är troligen att själva namngivningen, oavsett om det handlar om för- eller efternamn, är en könad handling. Vid förnamnsvalet väljer namngivaren, med mycket få undantag, antingen ett flick- eller ett pojknamn eftersom namnens könskonventioner är starka (Eckert \& McConnell-Ginet 2003:15, Gustafsson 2012:103). Förnamn, särskilt svenska och nordiska, har undersökts ur ett semantiskt genusperspektiv av Eva Brylla (2001a:20 ff., 2001b:41 ff.). Genom exempel visar hon hur traditionella könsroller för kvinnor och män kopplas till förnamnens betydelse på så sätt att männens namn oftare bär betydelser om krig, djärvhet, mod och styrka, medan kvinnonamnens komponenter består av skönhet, behaglighet, snällhet och vänlighet. Ett genusperspektiv har också applicerats på namnvalsprocessen av Emilia Aldrin (2014:180) som har studerat hur svenska föräldrar resonerar vid namnvalet beroende på babyns kön. Hon kommer fram till att flickor ofta får ett förnamn som av föräldrarna beskrivs som "gulligt, fint, mjukt, snyggt, sött, vackert", medan sönerna snarare får ett förnamn som beskrivs "coolt, enkelt, fräckt, kaxigt, kraftfullt, starkt, tufft". Även när det gäller skapandet av helt nya förnamn i Sverige visar Aldrin (2014:176 ff.; 2015:44 ff.) hur vissa drag upplevs som mer feminina än andra.

Med utgångspunkt i engelskt respektive tyskt namnmaterials fonologi har Herbert Barry och Aylene Harper (1995) respektive Susanne Oelkers (2003) och Damaris Nübling (2015) diskuterat hur genus kan skapas. De här forskarna har undersökt namnens fonem och stavelser för att se vilka drag som har uppfattats som kvinnliga respektive manliga. Ytterligare en tysk forskare, Miriam Schmidt-Jüngst (2015), har bidragit till undersökningsfältet genom att diskutera hur transsexuella personer i Tyskland väljer förnamn när de har genomfört den könskorrigerande operationen. Hon visar att vissa fonologiska drag hos förnamnen uppfattas som mer feminina än andra.

Den andra stora gruppen personnamn som har diskuterats ur ett genusperspektiv är efternamn. Oftast är det frågan om kvinnans efternamnsval i samband med äktenskap som har varit intressant. På svenskt material har Sonja Entzenberg (2006:kap. 4, 2007:206) visat hur kvinnor har förändrat sitt efternamnsmönster, i den utsträckning det har varit juridiskt möjligt, för att markera en ökande självständighet i förhållande till sin man. Följden av en större kvinnlig självständighet har blivit att alltfler kvinnor behåller sitt eget efternamn även som gifta. På liknande sätt har efternamnsfrågan behandlats i ett flertal undersökningar i USA och England av t.ex. Sara Mills (2003), Jean Twenge (1997) och Myleah Kerns (2011).

Även binamn har diskuterats ur genusperspektiv. Studier med en uttalad genusansats har genomförts dels i USA av Betty Phillips (1990), dels i Sydafrika av Vivian de Klerk och Barbara Bosch (1996). En pragmatisk undersökning av binamn, utan specifikt genusperspek- 
tiv men som ändå har betydelse för diskussionen i den här artikeln, har utförts av Michael Adams (2009). Baserat på en seriestripp av Peanuts (på svenska: Snobben) diskuterar Adams hur namnbäraren mer eller mindre kan tvingas acceptera ett binamn för att inte undergräva namngivarens självbild. Adams visar också att detta är mer invecklat när relationen mellan namnbrukarna i grunden är positiv; det är bättre att acceptera ett binamn som man inte uppskattar än att ställa hela relationens existens på sin spets. De komplicerade maktstrukturer som blottläggs kring binamn tydliggörs genom att vissa former är tecken på solidaritet och familjaritet när de används reciprokt, men om de används icke-reciprokt kan de istället uppfattas som respektlösa. Även motsatsen - att former som uttrycker respekt mellan samtalsdeltagarna markerar underordning och skillnad när de används icke-reciprokt - kan förekomma (Eckert \& McConnell-Ginet 2003:161).

Beträffande namn kan således den sociala laddningen som nämnts ovan bestå av en intimitet som skapas genom en viss namnform som endast används av ett fåtal personer. Det här är ofta ett binamn, men det skulle lika väl kunna vara andra typer av namn som används exklusivt mellan sändaren och mottagaren.

\section{Material}

Att arbeta med binamn innebär initialt vissa svårigheter eftersom materialet inte finns i några register och därför har namnen samlats in genom enkäter och intervjuer. Metoden för med sig både svagheter och styrkor, t.ex. svagheten med självrapportering som innebär att namnbärarna själva har berättat om de binamn de bär. Följaktligen har namnbäraren enbart uppgivit binamn som denne känner till och kommer ihåg. Minnet är ytterligare en svaghet med materialinsamlingsmetoden eftersom detta kan vara bristfälligt, särskilt när det gäller så alldagliga ting som binamn (Baddeley 1983:47). Däremot är det en styrka att tillvägagångssättet leder till att så kallade öknamn utesluts ur materialet, vilket etiskt sett har varit det korrekta eftersom tillkomsthistorierna runt öknamn ibland kan vara kränkande. Dessutom innebär det en möjlighet att studera alla de binamn som en person bär, vilket kan skilja sig åt mellan de grupper som personen ingår i. Motsatsen hade annars medfört att endast de binamn som namnbäraren bär i en specifik grupp hade inkluderats i undersökningen.

Det material som jag baserar mig på utgörs dels av 22 intervjuer, dels av 188 enkätsvar. Intervjuerna är 30-60 minuter långa och har förts som ganska fria samtal där vissa teman har kommit upp: familjesituation, vänner, barndom, skolgång, arbetsliv och fritidsintressen. Beträffande binamnen har informanterna diskuterat vad de tycker om namnen, vem som använder dem och i vilka situationer. Informanterna hade alla anknytning till Halmstad och högskolan. Flera av dem var studenter, andra var anställda på högskolans administrativa enhet och några var gifta med någon ur högskolans personalgrupp. Sammantaget innehåller materialet 311 binamn - 104 namn i intervjumaterialet och 207 i enkätmaterialet. Alla informanter och deltagare var myndiga vid insamlingstillfället, men de redogjorde för binamn som de hade burit under hela sitt liv, det vill säga även namn som hade burits tidigare men som av olika anledningar inte längre användes. Det finns en övervikt för kvinnliga informanter och deltagare, varför 197 binamn bärs av kvinnor och 114 av män. 


\section{Resultat}

I materialet ingår 311 binamn, 197 bärs av kvinnor och 114 av män. Eftersom fler kvinnor än män ingår i undersökningen bär kvinnor och män, trots skillnaden i absoluta tal, ungefär lika många binamn. Det är heller inte vanligt, med undantag av de mest konventionella binamnen t.ex. Mia, Nilla, Ninni, Sam och Stina, att flera personer i materialet bär samma binamn.

Till en början har materialet analyserats i en särdragsmodell som utgått från fyra olika aspekter: binamnens källa, bildning, innehåll och upplevd namngivningsorsak. I den här artikeln kommer jag att diskutera de infallsvinklar som har störst betydelse ur ett genusperspektiv, medan de andra endast kommer att beröras mycket kortfattat eller inte alls. Eftersom resonemanget baseras på informanternas och deltagarnas egna berättelser om tillkomsten av sina respektive binamn är det inte möjligt att med enbart ledning av själva namnet avgöra vilket särdrag som binamnet har, utan dess tillkomst är av avgörande betydelse.

Namnens källa är antingen onomastikonet eller lexikonet och vanligast är det att binamnen hämtas från vårt gemensamma onomastikon. Dessa binamn, t.ex. Kicki, Lasse, Maggan och Pelle, är nära förbundna med ett visst kön eftersom de hör ihop med könsbundna förnamn (t.ex. Gustafsson 2012:103 f., Schmidts-Jüngst 2015, Nübling 2015). Binamn som istället har hämtats från lexikonet kan upplevas som mer könlösa eftersom deras namnkaraktär inte alltid är lika stark. Utan ledning är det svårt att avgöra om t.ex. Gluten, Krullas, Lili, Pussel, Sorken, Touch och Vinkelhaken, bärs av kvinnor eller män. Andra gånger bärs samma binamn, t.ex. Knoppen och Pelle, av båda könen. Därtill förekommer mansnamnet Kenneth som binamn på en kvinnlig informant i mitt intervjumaterial. Mot den här bakgrunden går det att dra slutsatsen att könsneutrala binamn är vanligare än könsneutrala förnamn (jfr Gustafsson 2012:104 ff.).

Samtidigt föreligger dock en lika traditionell könsmarkering vid de finala ändelserna bland många binamn som vid svenska förnamn (jfr Aldrin 2014:176 f.) som framför allt berör binamn med en tydlig namnkaraktär. Binamnsändelserna $-a$, -an och -i(e) är vanligare vid binamn som bärs av kvinnor och - $e$ bland de som bärs av män. Binamn som slutar på - $a$ bärs av 26 kvinnor och 4 män, de på -an av 13 kvinnor och 4 män, de på -i(e) av 9 kvinnor och 1 man, medan binamn på - $e$ bärs av 3 kvinnor och 18 män. På liknande sätt förekommer ändelseskillnader i internationella binamn (Phillips 1990:283, de Klerk \& Bosch 1996:537).

När det gäller binamnens innehåll är det för den här artikelns vidkommande två av dragen, »händelse» och »egenskap», som lyfts fram eftersom analysen visar att just dessa särdrag har en särskild betydelse för genusidentiteten (Gustafsson 2016 s. 71 f.). Det förstnämnda särdraget har jag valt att avgränsa som en enskild händelse som inte inträffar upprepade gånger eller utgör utdragna och varaktiga skeende, då namnet istället har förts till särdraget »egenskap». När en händelse inträffar sker någonting aktivt, medan när en egenskap ligger till grund för binamnet är det snarare en passiv beskrivning av namnbärarens yttre eller inre karaktäristika drag som framträder genom binamnsvalet. Exempelvis har binamnet Pannan komponenten »händelse» eftersom namnbäraren fick namnet när han skallade en kompis, medan Turbo har komponenten »egenskap» eftersom binamnet beskriver namnbärarens sätt att tala (Gustafsson 2016 avsnitt 3.2).

Binamn som innehåller »händelse» förekommer i $2 \%$ av kvinnors binamn, t.ex. El-installation, Limpan och Röjes, och i $10 \%$ av männens binamn, t.ex. Apan, Barbaflott, Bullen, 
TBC och Touch. Skillnaden visar ett statistiskt samband. ${ }^{1}$ I kontrast till detta finns särdraget »egenskap» hos ungefär lika många kvinnliga som manliga binamn - $15 \%$ av kvinnornas binamn, t.ex. Krullas, Shorty, Sköldpaddan, Smulan och Turbo, och $14 \%$ hos männens, t.ex. Jean Paul och Myran. En försiktig tolkning av de ovan redovisade resultaten är att det förekommer binamnsskillnader som förstärker den traditionella könsrollen, där män utmålas som mer handlingskraftiga. Iakttagelsen förstärks också av att det internationellt har gjorts liknade observationer då kvinnors binamn i större utsträckning baseras på deras fysiska företräden, medan mäns baseras på t.ex. vanor, smak och karaktär (Phillips 1990:284).

Ytterligare en skillnad mellan kvinnors och mäns binamn som framträder i materialet är skillnaden vid den upplevda namngivningsorsaken »smeksamhet» då informanter och deltagare explicit anger att namnet uppfattas som ömt. Här uppger kvinnorna att $10 \%$ av deras binamn har tagits i bruk tack vare själva smeksamheten. Motsvarande andel bland männens binamn är $2 \%$, vilket visar ett statistiskt samband. ${ }^{2}$ Den här typen av smeksamhet mellan namnbrukarna - namngivaren och namnbäraren - ger också en positionsbestämmande signal till eventuella åhörare om att det förekommer en relation som denne är utesluten från. Genom detta ökar intimiteten ytterligare mellan sändare och mottagare.

Kvinnors binamn som innehåller särdraget »smeksamhet» är Baby, Dittapulla, Emmet, Fia, Gulle, Gullet, Hjärtat (2 st.), Lenigumman, Lillan, Loppan, Netta(n), Nompe, Pluttinuttan, Pussel, Smulan, Svetthjärtat, Teppe och Tumsen och mäns är (Farbror) Barba och Barbaflott som dessutom bärs av samme namnbärare. Slutligen finns det också anledning att fundera över hur genus skapades i intervju- eller enkätinsamlingsstadiet. Är det så att männen faktiskt bär färre binamn av det här slaget, något som i så fall speglar en språklig asymmetri, kommer männen inte ihåg sina smeksamma binamn lika bra som kvinnorna, eller vill de inte uppge dessa binamn för att de undergräver deras upplevda maskulinitet?

\section{Namngivningsmiljöer}

En annan aspekt av namnbruket är själva uppkomsten av binamnen och därmed den miljö där namngivningen äger rum. För att genomföra den här delen av undersökningen har jag endast baserat mig på 265 av de 311 binamnen eftersom den information som behövs inte har varit tillgänglig i alla intervjuer och enkäter. Materialet har delats in i sex namngivningsmiljöer, 1) barndomsfamilj/släkt, 2) barndomskamrater, 3) vänner i vuxen ålder (både som ung vuxen vid ankomsten till ett lärosäte eller på första jobbet, eller som något äldre vuxen), 4) idrottskontexten, 5) partnern och 6) övriga. Gränsdragningen mellan vissa grupper kan ibland vara svår. När det gäller barndomskamrater avses kamrater som hör till namnbärarens barndom och skolålder, eftersom kamrater i och utanför skolan ofta sammanfaller. Det är också svårt att skilja mellan barndomskamrater och vänner i vuxen ålder då det framträder en generationsskillnad beträffande själva vuxenblivandet. I materialet syns att fler äldre personer har börjat arbeta i, för en yngre generation betraktat, låg ålder. Därför har åtskillnaden mellan dem istället kommit att baseras på aktiviteter - barn- och skolaktiviteter å ena sidan och vuxenaktiviteter, t.ex. arbete eller eftergymnasiala studier, å andra.

\footnotetext{
${ }^{1} x^{2}$-analys ger: $\mathrm{p} 0,003$, df $1, x^{2} 8,867$.

${ }^{2} x^{2}$-analys ger: $\mathrm{p} 0,008$, df $1, x^{2} 7,140$.
} 
Vanligast är att binamn uppstår i barndomsfamiljen eller i barndomssläkten (34 \%). Binamn som uppkommer i den här miljön är mycket diversifierade och består av både konventionella binamn som Krille (m), Lisa (k), Lotta (k), Nettan (k), Pelle (m) samt Robban (m), och namn vars namnkaraktär är mindre tydlig, t.ex. Grodan (k), Mailen (m), Smulan (k) och Vinkelhaken (k). Inom namngivningsmiljön barndomskamrater uppkommer nästan lika många binamn (31\%) - som i barndomsfamiljen. Bland kvinnor finns t.ex. binamnen Gnaget, Jojjo, Lima, Linnet, Långkalsong, Saab, Sam, Sirran, Walle och Äpplet och bland männen t.ex. Bocaj, Myran, Putte, Salle, Sorken, Svesa, Sälen, Thordan och Warro.

Inom ramen för den tredje största namngivningsmiljön, vänner i vuxenlivet, har $16 \%$ av binamnen, t.ex. Amuel (m), Barbaflott (m), Betan (m), Blomman (m), Brö(gubben) (m), Bullen (m), Didrob (m), Gordon (m), Grynet (k), Jönsson (k), Kenneth (k), Limpan (k), Marado (k), Mary Jet (k), Nasse (k), Röjes (k), Sam (m), Sammetslena (k), Sussi (k), Tjorven (k), Turbo (k), Vivi (k) och YP (m), tillkommit.

En av de minsta namngivningsmiljöerna i materialet är idrottskontexten, som har varit grogrund för 4 \%, t.ex. Captain (m), Gahna (m), Lejoninnan (k), Sabbe (m), Säva (m), Söder $(\mathrm{m})$, Thierry Dali $(\mathrm{m})$ och Turk $(\mathrm{k})$, av binamnen. Trots att namnbeläggen inte är så många går det att se en tendens till överrepresentation (8 av 11) för manliga binamnsbärare i den här gruppen.

Ännu en namngivningsmiljö som har betydelse för binamnskapandet i vuxen ålder är partnern, som i rollen som namngivare oftast är en man, ligger bakom $6 \%$ av binamnen i materialet. $^{3}$ Det är i tolv fall en kvinna som fătt binamnet och en man som givit det. I ett fall då en man har uppgivit ett partnerbinamn är det ett mycket konventionellt namn, Uffe, och i ett annat fall är det namnet Bambi. De båda sista manliga partnerbinamnen bärs av samme man och de är (Farbror) Barba och Barbaflott. Motsvarande binamn för kvinnliga namnbärare är t.ex. Baby, Ella, Emmet, Gianni, Hjärtat, Huldur, Mica, Nela, Pussel, Sköldpaddan och Teppe. I min undersökning får i allmänhet inte dessa partnerbinamn någon spridning, utan de stannar mellan två personer som en intimitetsmarkör och emellanåt upplevs de så intima att informanten eller deltagaren har valt att inte uppge just dem i intervjun eller enkäten.

Inom den sista tillkomstmiljön, övriga, är namngivaren mer heterogen. Det kan t.ex. röra sig om vuxna personer som har arbetat i skolmiljö, och där fått binamn av barnen t.ex. Citronen (k), Futharken (m), Olle (m) och Sissan (k). I något fall har en pappa eller en mormor fått ett nytt binamn av barn eller barnbarn. Ibland har det också kommit in nya binamn i samband med att nya anhöriga har gifts in, t.ex. Gurro (k) som skapades av namnbärarens dotters svärmor som endast talade grekiska. Till den här namngruppen har jag fört $8 \%$ av binamnen. Figur 1 visar det förda resonemanget grafiskt.

\footnotetext{
${ }^{3}$ Ofta, men inte alltid, bär de här binamnen samtidigt särdraget »smeksamhet», men det ska inte blandas ihop eftersom ett binamn som skapas av partner inte automatiskt behöver vara smeksamt.
} 


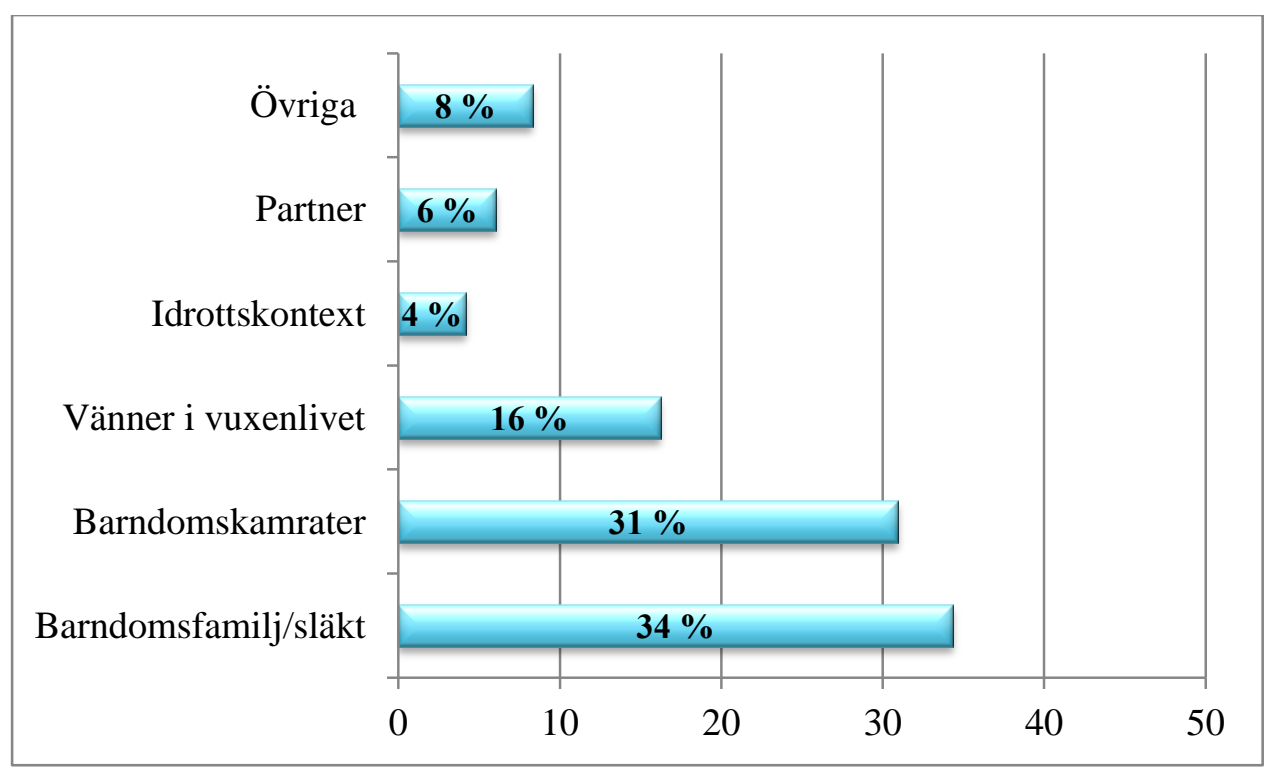

Figur 1: Binamnens namngivningsmiljöer

Om variabeln kön förs in i de sex namngivningsmiljöerna framträder vissa skillnader. För kvinnors del är det vanligast att få binamn i barndomsfamiljen, $42 \%$ av kvinnornas binamn att jämföra med 19 \% av männens (jfr de Klerk \& Bosch 1996). Även detta är en skillnad som visar ett statistiskt samband. ${ }^{4}$ För män är den vanligaste namngivningsgruppen barndomskamrater där $38 \%$ av deras binamn skapas. Också kvinnor får binamn i den här tillkomstmiljön, $27 \%$, men skillnaden som framträder är inte helt signifikant. ${ }^{5}$

När barnen har blivit unga vuxna får männen $18 \%$ av sina binamn och kvinnorna $15 \%$ av sina av vänner i vuxenlivet. Inom idrottskontexten, som innehåller ganska få binamn, skapas $2 \%$ av kvinnornas binamn och $9 \%$ av männens. Vidare kommer $5 \%$ av männens binamn och $7 \%$ av kvinnornas från en partner. Slutligen finns det $7 \%$ av de kvinnliga binamnen och $10 \%$ av de manliga dito som kommer från namngivningsgruppen övriga. Grafiskt illustreras detta i figur 2.

\footnotetext{
$4 x^{2}$-analys för barndomsfamilj/släkt ger: p 0,000, df $1, x^{2} 12,582$.

$5 x^{2}$-analys för barndomskamrater ger: p 0,085, df $1, x^{2} 2,960$.
} 


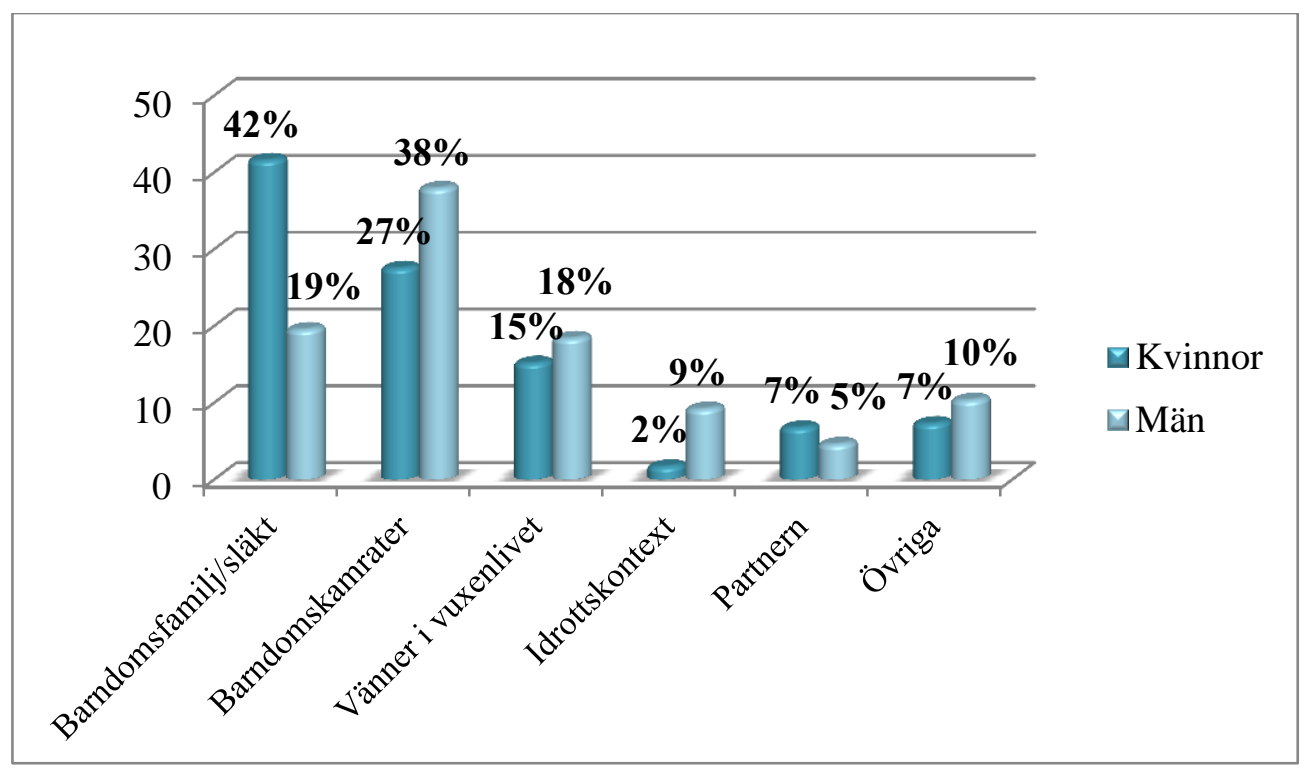

Figur 2: Namngivningsmiljöer där kvinnor respektive män får sina binamn

\section{Avslutning}

I den här artikeln har binamn och binamnsbruk diskuterats. I materialet synliggörs att binamnen såväl utjämnar som skapar och understryker könsskillnader. En del binamn har särdrag som kan föra med sig ett återskapande av traditionella könsroller. Vissa kvinnliga binamn bär t.ex. drag som innebär att namnen kan uppfattas som stereotyper för litenhet och intimitet: Baby, Gulle, Gullet, Hjärtat, Lillan, Pluttinuttan, Smulan, Svetthjärtat. Samma stereotypiserande drag går inte att avläsa vid männens binamn - inte ens bland de två namn, Farbror Barba och Barbaflott, som bär smeksamhetssärdraget. Den komponent av litenhet och underordning som ingår i den traditionella könskonstruktionen av 'kvinna' (Hirdman 2001:65) kan följaktligen föras över till namnbäraren genom försåtliga binamn som samtidigt inrymmer en ömhet som är positiv för namnbäraren. Det här kan alltså vara en del av könsidentiteten som konstrueras genom språket och godtas genom den alldagliga interaktionen. Genom det här förloppet återskapas genus. I vissa fall kan kvinnan uppfatta underordningen, men i enlighet med samma underordning är det tänkbart att hon i så fall istället väljer att respektera sin samtalspartners självbild som skulle kunna ha blivit sårad om hon avvisat binamnet (jfr Deuchar 1988:29 ff.).

Det går också att konstatera att kvinnor oftare än män får binamn i barndomsfamiljen eller av sin partner, det vill säga i de allra mest privata och intima sammanhangen. Den här observationen har även gjorts av de Klerk och Bosch (1996:532) som menar att både benämnandet och accepterandet av binamnet är direkt kopplat till makt. Eftersom kvinnor får fler binamn i intima miljöer understryker detta hennes underordning vis-à-vis först barndomsfamiljen och senare partnern. Tilltalsformen som väljs är socialt laddad med litenhet och intimitet som också markerar de sociala relationer som finns vid binamnets tillkomst och efterföljande användning. Resultatet blir återigen att könsrollen återskapas varje gång binamnet används samtidigt som det befäster den rådande intimiteten mellan samtalsparterna.

Däremot är binamn en mer manlig företeelse bland barndomskamraterna i skolåldern på samma sätt som dialektanvändningen i samma ålder, något som ofta används för att markera 
ungdomsidentitet och gruppidentitet (Eriksson 2005:73, Gunnarsdotter Grönberg 2004:kap. 9). Pojkar i den här åldern använder binamn för att signalera grupptillhörighet genom att de som inkluderas i gruppen bär en viss typ av binamn, medan de pojkar som anses vara veklingar utestängs från gemenskapen, vilket understryks av binamnsbruket eller snarare avsaknaden av detta (Best 1983:23 f.).

I jämförelse med kvinnors binamnsskapande är den kontext där männens binamn uppkommer - bland kamrater i skolan, på fritiden eller inom idrottskontexten - mer publik. Därför tycks binamn som bärs av kvinnor stå mer för intimitet än männens som istället indikerar solidaritet - inneslutning och uteslutning - på samma sätt som ungdomsspråket kan göra. Det här utmynnar i en genusidentitet med kvinnlig intimitet och manlig ungdomlig solidaritet. Genusskillnaden innebär att det förefaller vara en uppdelning i olika diskurser då kvinnor får binamn i den vardagligt privat-intima diskursen och män i den vardagligt gruppsolidariska (jfr de Klerk \& Bosch 1996:530). Genusskillnaden tycks spegla en intim och en solidarisk betydelse, på liknande sätt som pronomenet $d u$ hade i svenskan i samband med du-reformen (Paulston 1976:374).

Genom binamnsvalet kan maktförhållanden uppstå eller avvecklas, distans kan inträda och relationer befästas. Relationen som skapas kan uppfattas som både påtvingad eller frivillig av namnbäraren. I själva namngivningen kan det ligga såväl en önskan om en fördjupad relation med namnbäraren från namngivarens sida som en påtryckning om acceptans av relationen. Binamnsanvändning signalerar till både namnbäraren och eventuella åhörare att namngivaren har, eller önskar ha, en speciell relation med binamnsbäraren, något som i sig kan innehålla en dimension av makt. Maktaspekten kan, men behöver inte, kopplas till svårigheten som namnbäraren kan känna med att avvisa ett oönskat binamn då detta skulle kunna leda till att namngivarens självbild undergrävs. I det här läget är det vanligare att den underordnade parten väljer att försaka sin egen självbild till förmån för den andres (jfr Deuchar 1988:30 f.). På det här sättet kan den sociala laddning som finns i binamnet användas för att skapa och upprätthålla relationer mellan namnbrukarna och relationerna kan föra med sig maktstrukturer som blir synliga eller som förstärks genom binamnet.

Eftersom ett binamnsbruk kan innebära att situationen förändras kan det utgöra en illokut språkhandling som bidrar till att det görs kön av olika slag. När ett binamn används i samtalet är detta därför inte enbart en neutral benämning, utan ett binamn kan åstadkomma en social kategorisering utifrån talarens önskningar och behov. Binamnet kan öppna möjligheter, omgärda, beskära, bekräfta eller betvinga namnbäraren.

\section{Referenser}

Adams, Michael. 2009. Power, Politeness, and the Pragmatics of Nicknames. Names 57. S. 81-91.

Aldrin, Emilia. 2014. Förnamnsvalet som resurs för förhandling av könsidentiteter och könsgränser. SAS 32. S. 169-191.

Aldrin, Emilia. 2015. Att skapa kön Könsmönster och könsroller i nyskapade förnamn. I: Emilia Aldrin, Linnea Gustafsson, Maria Löfdahl \& Lena Wenner (red.). 2013. Innovationer $i$ namn och namnmönster. NORNA:s 43 symposium i Halmstad 6-8 november 2013. (NORNA-rapporter 92.) Uppsala: NORNA-förlaget. S. 36-52. 
Austin, John, L. 1975. How to do things with words. (2:a uppl.) Cambridge, Mass.: Harvard University Press.

Baddeley, Alan. 1983. Minnet. En bruksanvisning. Stockholm: Natur \& Kultur.

Barry, Herbert III \& Harper, Aylene S. 1995. Increased Choice of Female Phonetic Attributes in First Names. Sex Roles 32 (11/12). S. 809-819.

Best, Raphaela. 1983. We've All Got Scars: What Boys and Girls Learn in Elementary School. Bloomington: Indiana University Press.

Brown, Penelope \& Levinson, Stephen C. 1987. Politeness. Some universals in language usage. (Studies in interactional sociolinguistics 4.) Cambridge: Cambridge University Press.

Brylla, Eva. 2001a. Personnamn och genus. SAS 19. S. 11-29.

Brylla, Eva. 2001b. Personnamn och genus. Manligt och kvinnligt i namnen. I: Gunilla Harling-Kranck (red.), Namn i en föränderlig värld. Rapport från den tolfte nordiska namnforskarkongressen, Tavastehus 13-17 juni 1998. Helsingfors: Svenska litteratursällskapet i Finland. S. 36-44.

Butler, Judith. 1990. Gender Trouble. Feminism and the Suberversion of Identity. New York: Routledge.

Butler, Judith. 2004. The Judith Butler Reader. Ed. Sara Salih. Malden, Mass.: Blackwell Publishing.

Cameron, Deborah. 1990. The Feminist Critique of Language. A Reader. London: Routledge.

Cameron, Deborah. 1995. Verbal Hygiene. London: Routledge.

Connell, Raewyn. 2009. Om genus. 2:a uppl. Övers. av Charlotte Hjukström \& Anna Sörmark. Göteborg: Daidalos.

De Klerk, Vivian \& Bosch, Barbara. 1996. Nicknames as Sex-Role Stereotypes. Sex Roles 35(9/10). S. 525-541.

Deuchar, Margaret. 1988. A Pragmatic Account of Women's Use of Standard Speech. I: Jennifer Coates \& Deborah Cameron (eds.), Women in Their Speech Communities. New York: Longman. S. 27-32.

Eckert, Penelope \& McConnell-Ginet, Sally. 2003. Language and Gender. Cambridge: Cambridge University Press.

Entzenberg, Sonja. 2006. »Det får ju vara någon ordning på torpet!» Svenska personnamnregler $i$ ett historiskt perspektiv. Uppsala: Språk- och folkminnesinstitutet, småskrifter 2.

Entzenberg, Sonja. 2007. Professor Nanna Svartz eller Fru Nanna Malmberg? Släktnamnsbruk hos gifta kvinnor 1920-1982. I: Britt-Louise Gunnarsson, Sonja Entzenberg och Maria Ohlsson (red.), Språk och kön i nutida och historiskt perspektiv. Uppsala: Uppsala universitet. S. 198-207.

Eriksson, Lisa, 2005. En kvinna klär sällan i dialekt. Västerbotten 1. S. 64-74.

Foucalt, Michel. 1981. The Order of Discourse. I: Robert Young (ed.). Untying the Text: A Poststructuralist Reader. London: Routledge and Kegan Paul. S. 48-78.

Gastil, John, 1990. Generic Pronouns and Sexist Language: The Oxymoronic Character of Masculine Generics. Sex Roles 23(11-12). S. 629-643.

Gunnarsdotter Grönberg, Anna, 2004. Ungdomar och dialekt $i$ Alingsås. (Nordistica Gothoburgensia 27.). Göteborg: Göteborgs universitet.

Gustafsson, Linnea. 2012. What's an »Inappropriate» First Name? Some Socio-Ideological Changes and Some Linguistic Traits Relevant to a Reinterpretation of the Swedish Name Law. Onoma 47. S. 101-117.

Gustafsson, Linnea. 2016. Moderna vardagliga binamn i Sverige. (Namn och samhälle 29). Uppsala: Uppsala universitet.

Hirdman, Yvonne. 2001. Genus - om det stabilas föränderliga former. Malmö: Liber. 
Kerns, Myleah. 2011. North American Women's Surname Choice Based on Ethnicity and Self-Identification as Feminists. Names 59(2). S. 104-117.

McConnell-Ginet, Sally. 2003. „What's in a Name?» Social Labeling and Gender Practices. I: Janet Holmes \& Miriam Meyerhoff. (eds.), Handbook of Language and Gender. Oxford: Blackwell.

Milles, Karin. 2008. Jämställt språk. En handbok $i$ att skriva och tala jämställt. (Småskrift utarbetad av Språkrådet 5). Stockholm: Norstedts.

Mills, Sara. 2003. Caught between Sexism, Anti-Sexism and 'Political Correctness': Feminist Women's Negotiations with Naming Practices. Discourse \& Society 14(1). S. 87-110.

Mills, Sara. 2008. Language and Sexism. Cambridge: Cambridge University Press.

Nübling, Damaris. 2015. The Phonetic Gender Score of German First Names and Pet Names: Gendered First Names versus De-gendered Pet Names. I: Emilia Aldrin, Linnea Gustafsson, Maria Löfdahl \& Lena Wenner (red.), Innovationer $i$ namn och namnmönster. NORNA:s 43 symposium i Halmstad 6-8 november 2013. (NORNArapporter 92.) Uppsala: NORNA-förlaget. S. 196-215.

Oelkers, Susanne. 2003. Naming Gender. Empirische Untersuchungen zur phonologischen Struktur von Vornamen im Deutschen. Europäische Hochschulschriften. Reihe I. Deutsche Sprache und Literatur. Frankfurt am Main: P. Lang.

Paulston, Christina, Bratt. 1976. Pronouns of Address in Swedish: Social Class Semantics and a Changing System. Language in Society 5(3). S. 359-386.

Pauwels, Anne. 1996. Feminist Language Planning and Titles for Women: Some Crosslinguistic Perspektives. I: Marlis Hellinger \& Ulrich Ammon (eds.), Contrastive Sociolinguistics. Berlin: Mouton de Gruyter. S. 251-269.

Pauwels, Anne. 2003. Linguistic Sexism and Feminist Linguistic Activism. I: Janet Holmes \& Miriam Meyerhoff (eds.), The Handbook of Language and Gender. Oxford: Blackwell. S. 550-570.

Phillips, Betty. 1990. Nicknames and Sex Role Stereotypes. Sex Roles 23. S. 281-289.

Schmidt-Jüngst, Miriam. 2015. Constructing Gender Identity: Naming Choices of Transgender People in Germany. I: Emilia Aldrin, Linnea Gustafsson, Maria Löfdahl \& Lena Wenner (red.), Innovationer $i$ namn och namnmönster. NORNA:s 43 symposium i Halmstad 6-8 november 2013. (NORNA-rapporter 92.) Uppsala: NORNA-förlaget. S. 234-250.

Svahn, Margareta. 1999. Den liderliga kvinnan och den omanliga mannen: Skällsord, stereotyper och könskonstruktioner. Stockholm: Carlssons.

Talbot, Mary. 1998. Language and Gender. An Introduction. London: Polity.

Thornborrow, Joanna. 2002. Power Talk: Language and Interaction in Institutional Discourse. Harlow: Longman.

Twenge, Jean, M. 1997. «Mrs. His Name». Womens Preferences For Married Names. Psychology of Women Quarterly 21. S. 417-429.

West, Candice \& Zimmerman, Don. 1987. Doing Gender. I: Gender and Society 2(2). S. $125-151$.

Wojahn, Daniel. 2015. Språkaktivism. Diskussioner om feministiska språkförändringar $i$ Sverige från 1960-talet till 2015. (Skrifter utgivna av Institutionen för nordiska språk 92). Uppsala: Uppsala universitet. 